\title{
Arranging Haulage for Florida's Produce ${ }^{1}$
}

Richard Beilock ${ }^{2}$

\section{Introduction}

Over $99 \%$ of interstate shipments of Florida produce are by truck. Motor carriers do not magically know when there is a potential load they would find attractive. Rather, motor carriers and shipper/receivers must locate one another and negotiate terms, either directly or through an intermediary. This report will examine the methods used to arrange produce haulage and changes over the past two decades.

\section{Contact Via Brokers}

Truck brokers are agents, arranging matches between shipper/receivers and carriers and assisting in negotiation of terms. In some instances, brokers act as short-term lenders, advancing cash to carriers to cover costs related to a movement. Though legally not obligated to do so, brokers may also provide compensation in the event that either the carrier or shipper/receiver fails to fulfill the terms of the contract (this usually occurs only for long-term contracts). Brokers have traditionally been the dominant method for arranging transport of produce. Indeed, in the 1985/1986 Florida Driver Survey, 66\% of those hauling produce reported using brokers to secure the load (Figure 1). The critical role of these agents was reflected in the high frequency use of brokers and from the fact that carriers using brokers, on average, paid $8 \%$ of the freight rate. The frequency of use of brokers for produce haulage from Florida has remained essentially unchanged for the past 20 years, with 62\% in 2001/2002 (Appendix; Beilock, 2004). This is somewhat surprising considering the development and expanded use of communications technologies (e.g., cell phones, fax machines, and the Internet) which could facilitate direct contacts between carriers and shipper/receivers. Further evidence that brokers have maintained, if not improved, their position is that, while the average fee was $8 \%$ of the freight rate in the 1980 s, the average brokerage fee was $11 \%$ in 2001/2002 (the model fee was $10 \%$, with $12 \%$ as the second most common).
A. $1985 / 1986$

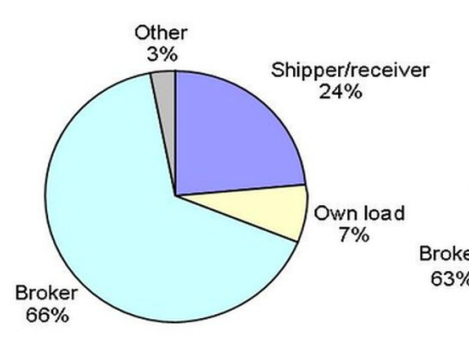

B. $2001 / 2002$

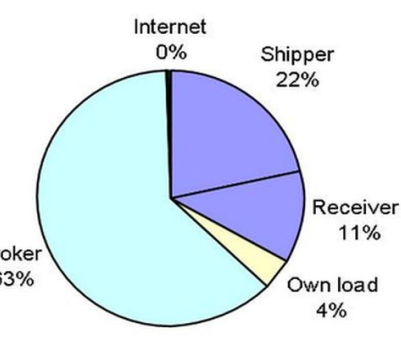

Figure 1. Produce load arrangement methods: 1985/1986 and $2001 / 2002$.

1. This is EDIS document, FE540, a publication of the Department of Food and Resource Economics, Florida Cooperative Extension Service, Institute of Food and Agricultural Sciences, University of Florida, Gainesville, FL. Published March 2005. Please visit the EDIS website at http://edis.ifas.ufl.edu.

2. Richard Beilock, Professor, Department of Food and Resource Economics, Florida Cooperative Extension Service, Institute of Food and Agricultural Sciences, University of Florida, Gainesville, FL.

The Institute of Food and Agricultural Sciences is an equal opportunity/affirmative action employer authorized to provide research, educational information and other services only to individuals and institutions that function without regard to race, color, sex, age, handicap, or national origin. For information on obtaining other extension publications, contact your county Cooperative Extension Service office. Florida Cooperative Extension Service/Institute of Food and Agricultural Sciences/University of Florida/Christine Taylor Waddill, Dean. 
As might be expected, lacking specialized, in-house sales staffs, owner-operators are more likely to use brokers than larger carriers. While statistically significant, this difference is surprisingly small $(66 \%$ and $58 \%$, respectively).

\section{Direct Contact with Shippers or Receivers}

Comparing the results for 1985/1986 and $2001 / 2002$, there appears to be some increase in load arranging via direct contacts between carriers and their customers, the shipper/receivers. In 1985/1986, approximately a quarter of loads were arranged through direct contacts, versus a third in 2001/2002 (Figure 1). In 2001/2002, 22\% of the drivers indicated that produce loads had been arranged through the shipper in Florida and 11\% through the receiver at the destination (Figure 1). It should be noted that produce is almost always shipped FOB origin, meaning that the receiver owns the product during, and is responsible for, the transport (Pavlovic, et al., 1980). Therefore, it is likely, in the very large number of cases where "shipper" was indicated, that the shipper arranged the transport on behalf of the receiver.

\section{Contact Via Internet}

When asked if they ever have used the Internet to hunt for loads, two-thirds of the owner-operators responded positively. In practice, however, the Internet appears to be of marginal importance, at best. Less than $1 \%$ of owner-operators indicated that the load on their trucks at the time of the interview had been secured through the Internet (Figure 1).

\section{Summary}

Despite improvements in communications, which might make it easier for shipper/receivers and carriers to locate one another without an intermediary, brokers remain the dominant method for arranging produce loadings from Florida. Indeed, judging by their fees, the importance of brokers appears to have increased. In 1985/1986, the average broker charged $8 \%$ of the freight rate for its services. In $2001 / 2002$, this had risen to $10 \%$.
The Internet may yet transform how produce loadings are arranged. However, that has barely begun. In the 2001/2002 survey, two-thirds of owner-operators reported that they had sought loads through the Internet, but less than $1 \%$ of their truck loads was through this source.

\section{References}

Beilock, R. 2004. Long Distance Refrigerated Trucking: A Florida Case Study. Report prepared for the Agricultural Marketing Service, United States Department of Agriculture, Washington, D.C.

Beilock, R., J. MacDonald, and N. Powers. 1988. An Analysis of Produce Transportation: A Florida Case Study. ERS/USDA Agricultural Economic Report 597, United States Department of Agriculture, Washington, D.C. 43pp.

Pavlovic, K., G. Long, D. Reaves, and T. Maze. 1980. Domestic Transportation for Florida Perishable Produce. Transportation Research Center Report, University of Florida, Gainesville, FL.

Ying, J., and T. Keeler. 1991. Pricing in a Deregulated Environment. RAND Journal of Economics 22:264-73.

\section{Appendix: Data}

The 2001/2002 Driver Survey: This survey was conducted in November of 2001, and in January, March, and May of 2002. The survey sites included the Florida Agricultural Inspection Stations located on interstate highways U.S. I-10, U.S. I-75, and U.S. I-95. The drivers of 1,642 refrigerated tractor-trailers were interviewed as they exited the Florida Peninsula.

While the survey sites were all in Florida, the study has relevance for long-distance haulage throughout North America. The sample contained drivers from all 48 contiguous U.S. states and 8 Canadian provinces. These drivers were enroute to destinations in 46 states, the District of Columbia, and 7 Canadian provinces. Trip distances ranged from 100 to 3,347 miles, averaging 1,222 miles. 